\title{
A Study of Urban Transportation System in Osogbo, Osun State, Nigeria.
}

\author{
S. B. Adedotun ${ }^{1}$
}

\begin{abstract}
The study examines the movement pattern of urban residents, mode of transport often used by the residents and assessment of transport infrastructure in the area. Primary data was used for the study. The data was derived from field work which involved direct interview and administration of questionnaire to the residents of the city. Random and systematic sampling techniques were used in the selection of the respondents in the area. Descriptive statistics such as tabulations and percentages were used in the presentation and analysis of the data. The study however reveals that most of the commuters depend on the use of motor-cycles and 'korope' (mini bus) for their daily movement, while significant number of the trips made are to the work place and schools. The study further shows that substantial number of the roads are in a deplorable condition that requires urgent attentions. In addition basic transport infrastructure are lacking such as drainage, walk way, street light, traffic light. The paper therefore suggests enabling policy environment for private -public participation in provision, maintenance and management of transport facilities which will enhance sustainable urban transportation system in our cities.
\end{abstract}

Key words: Urban transportation, Urban residents, Mode of transport, Transport infrastructure.

\section{Introduction}

Transportation is a process that involves movement of commuters, goods and services from a given point of origin to a specific destination (Okoko, [1]). It determines the regional patterns of development, economic viability, environmental impacts, and maintenance of socially acceptable levels of quality of life [2].

It also paves way for growth of economic activities in both rural and urban areas, which serves as a catalyst to rapid development of all nations. Transportation is an integral part of the functioning of any society and advances in transportation have made possible changes in the way we live and the way societies are organized [3].

The evolvement of modern transportation systems has catapulted the increase in level of civilization and urbanization; which has also increased the potency of economic wellbeing of the nation and at the same time caused numerous problems for nations across the globe. Mabogunje [4] shares the views that urbanization process has shown that there have been rapid rate of urbanization over the decades and that this has not been matched with corresponding increase in transportation facilities, hence mobility and accessibility problems set in.

Therefore, when there are inadequate facilities and mechanism capable of facilitating efficient and effective transportation, there is hardly any human settlement 
that can function effectively, as a result of this inadequacy, mobility and accessibility of the people are crippled, which is one of the major problems facing the world cities today. The situation is not different in Osogbo, Osun State Capital, Nigeria, a growing city with challenges of effective transportation system which require urgent attention, hence the need for this study.

\section{Statement of the problem}

Problems pervading urban transport sector in most developing countries range from inadequate and poor quality of infrastructure, mismatch between demand and supply to increased rate of accidents. The problems are triggered by interrelated trends such as urban population growth; unplanned and uncoordinated growth of cities [2].

Effective transportation system is essential for the economy of a city; consequently, the priority accorded to the planning of transportation system is immense. The transportation system in Nigeria is overrun by private entrepreneurs. These private entrepreneurs operate in an uncontrolled manner and provide erratic and unreliable services [5].

In the study area, there is no known public mass transit system; this has compounded the problem of mobility in the study area. Mobility problem in Nigeria has reached a crisis stage; this was exemplified by inadequacy of public transport service relative to proliferated, disorganized and uncontrolled Para-transit operators [6].

The increased pressure on road transportation as brought about other constraints to mobility and accessibility of people. Most of the scholars who have worked on urban transport problems in Nigeria have identified congestion as the most serious. Congestion occurs when transport demand exceeds transport supply at a specific point in time and in a specific section of the transport systems [7]. Associated with the traffic congestions are problems of parking. Parking demands far outweigh the available supply in most Nigerian cities [8]. This results in road-side parking and illegal parking, which are common features in urban centres of Nigeria, These problems leads to others such as pollution, and ultimately auto-accidents.

These problems identified can reduce the inputs of other sectors to the economy of the area i.e. health care, commercial, industrial and educational facilities. This inevitably discourages possible investment, especially by foreign investors, which if not addressed quickly, will cripple the economy and social wellbeing of the study area.

Aim: The aim of this paper is to study urban transportation system in the study area with a view to identifying challenges faced by people in terms of mobility and accessibility in the study area.

Objectives:

(i) Examine movement pattern of urban residents

(ii) Determine modes of movement often used by the residents of the study area

(iii) Make an assessment of road transport infrastructure in the study area. 


\section{The study area}

The study area is Osogbo the capital city of Osun State between latitude $7_{0} 46$ ' N, longitude $4034^{\prime} \mathrm{E}$ and $7.767_{\mathrm{o}} \mathrm{N}, 4.567_{\mathrm{o}} \mathrm{E}$. Osogbo has two local government areas (Osogbo and Olorunda Local Governments). Based on 2006 census (provisional result) the population of Osogbo is above 287,156 people [9]. Osogbo has been a major centre in Osun division since the colonial period. The city becomes a commercial center with the arrival of railway in 1907 which brought the colonial government of then to the threshold of the town. The town is now a highly commercial town. The busiest and most commercial parts of the town are Ajegunle, Old garage/Orisumbarearea;Olaiya/OgoOluwa area; Igbona/Ayetoro Area; and the area along $\mathrm{Oja}-\mathrm{Oba} / \mathrm{Station}$ road. Along these areas are activities which generate trips in the town. Furthermore, Osogbo is the home of art and culture in the Yoruba traditional history. The ever-popular and crowd pulling annual OsunOsogbo festival shows that the people of Osogbo has preserved their cultural identity. This has earned the festival UNESCO recognition. The Osun groove today is a tourist center of international recognition. All these impact the movement pattern in the city.

\section{Research Methodology}

This research work used primary and secondary methods of data collection and descriptive and analytical methods of data analysis. Primary Data was collected through the use of questionnaires, personal interview and direct observation. The questionnaire was administered to respondents on household basis.

Osogbo has twenty three (23) political wards, out of which six (6) were randomly selected. For the purpose of this research work 1\% (221) of the household size in the selected wards was systematically and randomly picked (table 1) for investigation.

Secondary data were collected from relevant publications and institutions for population data and concepts. In presentation and analysis of the data, cross tabulation, percentages, regression model, and analysis of variance were used.

Table 1: Estimated population of sample size for selected wards in the study area

\begin{tabular}{|l|l|l|l|l|l|l|}
\hline S/N & Wards & Density & $\begin{array}{l}1991 \\
\text { population }\end{array}$ & $\begin{array}{l}\text { Estimated } \\
2014 \\
\text { Population }\end{array}$ & $\begin{array}{l}\text { Estimated } \\
\text { No } \\
\text { of } \\
\text { household }\end{array}$ & $\begin{array}{l}\text { Household } \\
\text { sample } \\
\text { size (1\%) }\end{array}$ \\
\hline 1 & Isale-osun & High & 17,336 & 35,764 & 7,153 & 72 \\
\hline 2 & Alekuwodo & High & 14,823 & 30,589 & 6,118 & 61 \\
\hline 3 & Agowande & Medium & 7,204 & 14,862 & 2,972 & 30 \\
\hline 4 & Oke-fia & Medium & 7,001 & 14,443 & 2,889 & 29 \\
\hline 5 & Owode & Low & 4,010 & 8,273 & 1,655 & 17 \\
\hline 6 & Oke-Ayepe & Low & 2,958 & 6,102 & 1,220 & 12 \\
\hline & Total & & 53,332 & 110,033 & 22,007 & 221 \\
\hline
\end{tabular}

Source: Field work, 2014. 


\section{Presentation and analysis of data}

\subsection{Means of Transportation}

Table 2 shows the respondents' means of transportation in the study area. The study revealed that in Alekuwodo which falls within the high density area of the city, 34.4\% make use of private car, 29.5\% make use of motor cycle, 19.7\% make use of bicycle, 9.8\% make use of mini-bus (Korope), 4.9\% make use of taxi and 1.6\% prefers trekking respectively. In IsaleOsun which is also a high density area, the majority of the respondents make use of mini-bus (Korope) with 44.4\%, 31.9\% make use of private car, $18.1 \%$ make use of motorcycle, $4.2 \%$ prefers taxi and $1.4 \%$ prefers trekking respectively. In Agowande, a medium density area within the city, majority of the respondents in the area make use of motorcycle with $53.3 \%$ followed by private car users with $26.7 \%$, minibus (Korope) users with $16.7 \%$ and $3.3 \%$ prefers taxi. In Oke-fia, a medium density area too, majority of the respondents make use of motorcycle compared to other means of transportation with 31\%, 27.6\% each make use of Mini-Bus and Private Cars, while $6.9 \%$ prefers taxi, and 3.4\% each for both tricycle and bicycle. In Owode a low residential area, majority prefers the use of motorcycle $(41.2 \%)$, followed by respondents with the use of private cars (35.3\%), 17.6\% prefers the use o "Korope" (mini-bus)f and $5.9 \%$ make use of taxi. .In Oke-Ayepe, a low residential area also majority of the respondents make use of motorcycle $(58.3 \%$ ), followed by $16.7 \%$ respondents that make use of private cars and 8.3\% each prefers trekking, bicycle and "Korope" (mini-bus).

Table 2 in summary shows that greater numbers $(31.7 \%$ ) of the commuters in the study area preferred the use of motorcycles for their intra-city movement, which is predominantly in use in the area. This is closely followed by private car owners $(30.8 \%)$, while $24.9 \%$ of the commuters also make use of "korope" for their intra-city movement. The use of taxi is not popular in the study area. It has almost gone into extinction.

The chi-square statistical test also shows that there is significant relationship within preference of transportation means and the selected areas (location) within the city with the $\mathrm{p}$ value $<0.05=0.000$. It shows that there is no significant difference in the means of intra-city movement among different residential density areas of the city.

Table 2: Means of Transportation

\begin{tabular}{|c|c|c|c|c|c|c|c|c|c|}
\hline \multirow[b]{2}{*}{ Areas } & & \multicolumn{7}{|c|}{ Means of transportation } & \multirow[b]{2}{*}{ Total } \\
\hline & & Trekking & bicycle & motorcycle & tricycle & $\operatorname{taxi}$ & $\begin{array}{c}\text { private } \\
\text { car }\end{array}$ & $\begin{array}{l}\operatorname{mini} \text { bus } \\
\text { (korope) }\end{array}$ & \\
\hline \multirow[t]{2}{*}{ Alekuwodo } & Count & 1 & 12 & 18 & 0 & 3 & 21 & 6 & 61 \\
\hline & $\%$ & $1.6 \%$ & $19.7 \%$ & $29.5 \%$ & $.0 \%$ & $4.9 \%$ & $34.4 \%$ & $9.8 \%$ & $100 \%$ \\
\hline \multirow[t]{2}{*}{ Isale Osun } & Count & 1 & 0 & 13 & 0 & 3 & 23 & 32 & 72 \\
\hline & $\%$ & $1.4 \%$ & $.0 \%$ & $18.1 \%$ & $.0 \%$ & $4.2 \%$ & $31.9 \%$ & $44.4 \%$ & $100.0 \%$ \\
\hline \multirow[t]{2}{*}{ Ago wande } & Count & 0 & 0 & 16 & 0 & 1 & 8 & 5 & 30 \\
\hline & $\%$ & $.0 \%$ & $.0 \%$ & $53.3 \%$ & $.0 \%$ & $3.3 \%$ & $26.7 \%$ & $16.7 \%$ & $100.0 \%$ \\
\hline \multirow[t]{2}{*}{ Okefia } & Count & 0 & 1 & 9 & 1 & 2 & 8 & 8 & 29 \\
\hline & $\%$ & $.0 \%$ & $3.4 \%$ & $31.0 \%$ & $3.4 \%$ & $6.9 \%$ & $27.6 \%$ & $27.6 \%$ & $100.0 \%$ \\
\hline \multirow[t]{2}{*}{ Owode } & Count & 0 & 0 & 7 & 0 & 1 & 6 & 3 & 17 \\
\hline & $\%$ & $.0 \%$ & $.0 \%$ & $41.2 \%$ & $.0 \%$ & $5.9 \%$ & $35.3 \%$ & $17.6 \%$ & $100 \%$ \\
\hline \multirow[t]{2}{*}{ OkeAyepe } & Count & 1 & 1 & 7 & 0 & 0 & 2 & 1 & 12 \\
\hline & $\%$ & $8.3 \%$ & $8.3 \%$ & $58.3 \%$ & $.0 \%$ & $.0 \%$ & $16.7 \%$ & $8.3 \%$ & $100.0 \%$ \\
\hline \multirow[t]{2}{*}{ Total } & Count & 3 & 14 & 70 & 1 & 10 & 68 & 55 & 221 \\
\hline & $\%$ & $1.4 \%$ & $6.3 \%$ & $31.7 \%$ & $.5 \%$ & $4.5 \%$ & $30.8 \%$ & $24.9 \%$ & $100.0 \%$ \\
\hline
\end{tabular}




\subsection{Regression analysis of socio-economic characteristics of respondents and travel pattern}

To determine the relationship between socioeconomic characteristics of respondents and travel pattern in Osogbo city, the socioeconomic characteristics was regressed (multiple regression) on the following components: (i) gender (ii) age (iii) marital status (iv) occupation (v) monthly income (vi) level of education. The results of multiple regression analysis are shown in tables $3 \mathrm{a}, 3 \mathrm{~b}$ and $3 \mathrm{c}$.

With F-value of 4.080 and P- value of 0.001 in table 3b, it is observed that the relationship between socio-economic characteristics of respondents and travel pattern is significant. Moreover with correlation coefficient (R) of 0.736 and co-efficient of multiple determination $\left(\mathrm{R}^{2}\right)$ of 0.543 as shown in table $3 \mathrm{a}$, one observes that $54 \%$ of mobility pattern are determined by the socio- economic characteristic of respondents. In other words, $54 \%$ of the variability of travel pattern maybe attributed to magnitude increase in socio economic characteristics.

To determine the weight of each of the component/factor of socio economic characteristics, reference is made to their regression in table $3 \mathrm{c}$. Using the standardized beta coefficient, the constant 'a' would disappear and the regression equation is of the form

$\mathrm{Y}=\mathrm{a}+\mathrm{b}_{1} \mathrm{x}_{1}+\mathrm{b}_{2} \mathrm{x}_{2}+\mathrm{b}_{3} \mathrm{x}_{3}+\mathrm{b}_{4} \mathrm{x}_{4}+\mathrm{b}_{5} \mathrm{x}_{5}+\mathrm{b}_{6} \mathrm{x}_{6}$

Becomes:

$\mathrm{Y}=0.298 \mathrm{x}_{6}+0.282 \mathrm{x}_{5}+0.153 \mathrm{x}_{4}+0.028 \mathrm{x}_{3}+0.033 \mathrm{x}_{2}+0.102 \mathrm{x}_{1}$

That is, the regression co-efficient factor 1 , factor 2 , factor 3 , factor 4 , factor 5 and factor 6 from table $3 c$ are $0.102,0.033,0.028,0.153,0.282$ and 0.298 respectively, this shows the influence of each factor in explaining travel pattern i.e. factor 6 (level of education) has the most effect on travel pattern while factor 3 (marital status) has the least effect on travel pattern.

From the result of this multiple regression analysis, the study shows a significant relationship between socio-economic characteristics and travel pattern of respondents.

Table 3: Regression Model Summary

\begin{tabular}{|l|l|l|l|l|}
\hline Model & R & R Square & Adjusted R Square & Std. Error of the Estimate \\
\hline 1 & $.736^{\mathrm{a}}$ & .543 & .108 & 228.746 \\
\hline
\end{tabular}

a. Predictors: (Constant), Level of Education, Gender, Age, Marital Status, Occupation, Monthly Income

Table 5: Test of Statistical Significance of Regression Model

\begin{tabular}{|lllllll|}
\hline & & & & & \\
Model & & Sum of Squares & df & Mean Square & F & Sig. \\
\hline 1 & Regression & 1280968.607 & 6 & 213494.768 & 4.080 & $.001(\mathrm{a})$ \\
& Residual & 7691709.477 & 147 & 52324.554 & & \\
& Total & 8972678.084 & 153 & & & \\
\hline
\end{tabular}


a. Predictors: (Constant), Level of Education, Gender, Age, Marital Status, Occupation, Monthly Income

b. Dependent Variable: Travel Pattern

Table 5: Regression Coefficients

\begin{tabular}{|c|c|c|c|c|c|c|}
\hline \multirow[b]{2}{*}{ Model } & & \multicolumn{2}{|c|}{$\begin{array}{l}\text { Unstandardized } \\
\text { Coefficients }\end{array}$} & \multirow{2}{*}{$\begin{array}{l}\text { Standardized } \\
\text { Coefficients } \\
\text { Beta }\end{array}$} & \multirow[b]{2}{*}{ B } & \multirow{2}{*}{$\begin{array}{l}\text { Sig. } \\
\text { Std. } \\
\text { Error }\end{array}$} \\
\hline & & B & $\begin{array}{l}\text { Std. } \\
\text { Error }\end{array}$ & & & \\
\hline \multirow[t]{7}{*}{1} & (Constant) & 285.036 & 129.211 & & 2.206 & .029 \\
\hline & Gender & -49.849 & 37.729 & .102 & $-\overline{1.321}$ & .188 \\
\hline & Age & 6.982 & 18.398 & .032 & .379 & .705 \\
\hline & Marital Status & 8.633 & 24.770 & .028 & .349 & .728 \\
\hline & Occupation & -26.882 & 14.352 & .153 & $-\overline{1.873}$ & .063 \\
\hline & Monthly Income & -39.984 & 12.612 & .282 & - & .002 \\
\hline & $\begin{array}{ll}\text { Level of } \\
\text { Education }\end{array}$ & 67.445 & 18.875 & .298 & 3.573 & .000 \\
\hline
\end{tabular}

a. Dependent Variable: Travel Pattern

Source: 2014, field work

\subsection{Travel/mobility pattern of the people in the study area}

Table 4 shows the differences in the travel/mobility pattern of respondents in the study area, Osogbo. According to the table, with F- value 12.576, 7.449, 17.5803 .734 and pvalue of $0.000,0.000,0.000$ and 0.004 , for work/school trips, social trips, market trips and recreational trips, the study shows that there are significant differences in the travel/mobility pattern of the people in the study area as the P values are less than 0.05 .

Table 6: Analysis of variance of differences in the travel/mobility pattern of people in the study area

\begin{tabular}{|l|l|r|r|r|c|c|}
\hline & & $\begin{array}{c}\text { Sum of } \\
\text { Squares }\end{array}$ & \multicolumn{1}{c|}{ df } & $\begin{array}{c}\text { Mean } \\
\text { Square }\end{array}$ & \multicolumn{1}{c|}{ F } & Sig. \\
\hline \multirow{2}{*}{$\begin{array}{l}\text { Destination of } \\
\text { Work/school trips weekly? }\end{array}$} & Between Groups & 4999.114 & 5 & 999.823 & 12.576 & .000 \\
\cline { 2 - 7 } & Within Groups & 15344.243 & 193 & 79.504 & & \\
\cline { 2 - 7 } & Total & 20343.357 & 198 & & & \\
\hline \multirow{2}{*}{$\begin{array}{l}\text { Destination of social trips } \\
\text { weekly? }\end{array}$} & Between Groups & 2986.965 & 5 & 597.393 & 7.449 & .000 \\
\cline { 2 - 8 } & Within Groups & 13072.040 & 163 & 80.197 & & \\
\cline { 2 - 8 } & Total & 16059.006 & 168 & & & \\
\hline \multirow{2}{*}{$\begin{array}{l}\text { Destination of Market trips } \\
\text { weekly? }\end{array}$} & Between Groups & 2976.136 & 5 & 595.227 & 17.580 & .000 \\
\cline { 2 - 8 } & Within Groups & 3927.471 & 116 & 33.858 & & \\
\cline { 2 - 8 } & Total & 6903.607 & 121 & & & \\
\hline \multirow{2}{*}{$\begin{array}{l}\text { Destination of recreational } \\
\text { trips weekly? }\end{array}$} & Between Groups & 1091.172 & 5 & 218.234 & 3.734 & .004 \\
\cline { 2 - 7 } & Within Groups & 4909.950 & 84 & 58.452 & & \\
\cline { 2 - 7 } & Total & 6001.122 & 89 & & & \\
\hline
\end{tabular}




\subsection{Road Attributes and Furniture in Osogbo}

Table 5 shows the attributes of the major roads in the study area. The total length of the roads surveyed is $49 \mathrm{~km}$. The study showed that only $34.7 \%$ of the roads surveyed made up of four lanes of dual carriage road while, the remaining 65.3\% made up of 2 lanes of single carriage way. Most of the roads surveyed are characterized with a lot of potholes of various sizes. In all, 1,456 potholes were counted as shown in table 5. The study showed that for an average of $1 \mathrm{~km}$, there are about 30 potholes with an average of $3.8 \mathrm{~cm}$ deep. The field observation revealed that most of the roads in the study area do not have good drainage system which resulted in storm water that erodes the road ways. The study also showed that all the roads surveyed are tarred with bitumen but most of them are at the state of disrepair and need urgent attention. The study further revealed that most of the roads in the study area have few or no road signs to alert the motorist of the road conditions. Most of the routes have no street light and where it exist, they are not functioning except along Olaiya- Abere route. Most of the people interacted with during the field observation also express various degree of inconveniences they pass through in the cause of their movement in the study area, such as delay on the road, wear and tears on the vehicles due to poor conditions of most roads.

Table 7: Road attributes and furniture in the study area

\begin{tabular}{|c|c|c|c|c|c|c|c|c|}
\hline Routes & $\begin{array}{l}\text { Distance } \\
(\mathrm{km})\end{array}$ & $\begin{array}{l}\text { No. of } \\
\text { lanes }\end{array}$ & Surface conditions & $\begin{array}{l}\text { Drainage } \\
\text { system }\end{array}$ & $\begin{array}{l}\text { No. of } \\
\text { potholes }\end{array}$ & $\begin{array}{l}\text { Avg depth } \\
\text { of pot } \\
\text { holes }(\mathrm{cm})\end{array}$ & $\begin{array}{l}\text { Street } \\
\text { Light }\end{array}$ & Remarks \\
\hline $\begin{array}{l}\text { Kobongbogboe } \\
\text { - Ayetoro }\end{array}$ & 7 & 2 & $\begin{array}{l}\text { Tarred with } \\
\text { bitumen but state } \\
\text { of disrepair }\end{array}$ & $\begin{array}{l}\text { No } \\
\text { drainage } \\
\text { facility. }\end{array}$ & 351 & 5 & N/A & $\begin{array}{l}\text { Under } \\
\text { construction } \\
\text { into dual } \\
\text { carriage of } 4 \\
\text { lanes }\end{array}$ \\
\hline $\begin{array}{l}\text { Ayetoro-Old } \\
\text { garage }\end{array}$ & 2 & 2 & $\begin{array}{l}\text { Tarred with } \\
\text { bitumen but state } \\
\text { of disrepair }\end{array}$ & $\begin{array}{l}\text { No } \\
\text { drainage } \\
\text { facility. }\end{array}$ & 25 & 3 & $\begin{array}{l}\mathrm{A}, \\
\mathrm{NF}\end{array}$ & $\begin{array}{l}\text { Under } \\
\text { construction } \\
\text { into dual } \\
\text { carriage of } 4 \\
\text { lanes }\end{array}$ \\
\hline Olaiya-Abere & 6 & 4 & $\begin{array}{l}\text { Tarred with } \\
\text { bitumen. }\end{array}$ & Fairly okay & 05 & 3 & A & Smooth surface \\
\hline $\begin{array}{l}\text { Olaiya - } \\
\text { IsaleAro }\end{array}$ & 3 & 4 & $\begin{array}{l}\text { Tarred with } \\
\text { bitumen but state } \\
\text { of disrepair }\end{array}$ & $\begin{array}{l}\text { Poorly } \\
\text { drained. }\end{array}$ & 280 & 5 & N/A & $\begin{array}{l}\text { Need urgent } \\
\text { attention }\end{array}$ \\
\hline $\begin{array}{l}\text { Aregbe bus } \\
\text { stop-Capital } \\
\text { hotel }\end{array}$ & 2 & 2 & $\begin{array}{l}\text { Tarred with } \\
\text { bitumen. }\end{array}$ & Good. & - & & N/A & $\begin{array}{l}\text { Smooth } \\
\text { surfaces }\end{array}$ \\
\hline $\begin{array}{l}\text { West bye pass } \\
\text { ring road }\end{array}$ & 7 & 4 & $\begin{array}{l}\text { Tarred with } \\
\text { bitumen. }\end{array}$ & $\begin{array}{l}\text { Over grown } \\
\text { with weeds }\end{array}$ & - & & $\begin{array}{l}\mathrm{A}, \\
\mathrm{NF}\end{array}$ & $\begin{array}{l}\text { Drainage to be } \\
\text { cleared }\end{array}$ \\
\hline $\begin{array}{l}\text { Oja-oba-Power } \\
\text { line junction }\end{array}$ & 4 & 2 & $\begin{array}{l}\text { Tarred with } \\
\text { bitumen but with } \\
\text { a lot of potholes. }\end{array}$ & Poor. & 241 & 4 & N/A & $\begin{array}{l}\text { State of } \\
\text { disrepair, needs } \\
\text { attention }\end{array}$ \\
\hline $\begin{array}{l}\text { Old garage- } \\
\text { Oja-oba - Ilesa } \\
\text { garage }\end{array}$ & 5 & 2 & $\begin{array}{l}\text { Tarred with } \\
\text { bitumen }\end{array}$ & Poor. & 65 & 3 & N/A & Fairly okay \\
\hline $\begin{array}{l}\text { Oke-fia- } \\
\text { Okinni }\end{array}$ & 5 & 2 & $\begin{array}{l}\text { Tarred with } \\
\text { bitumen with a lot } \\
\text { of potholes }\end{array}$ & Poor. & 410 & 4 & N/A & $\begin{array}{l}\text { State of } \\
\text { disrepair, needs } \\
\text { attention }\end{array}$ \\
\hline $\begin{array}{l}\text { Oja-oba - } \\
\text { OSBC }\end{array}$ & 4 & 2 & $\begin{array}{l}\text { Tarred with } \\
\text { bitumen }\end{array}$ & Poor. & 79 & 4 & N/A & Fairly okay \\
\hline $\begin{array}{l}\text { Lameco } \\
\text { junction- } \\
\text { Capital Hotel }\end{array}$ & 2 & $4 ; 2$ & $\begin{array}{l}\text { Tarred with } \\
\text { bitumen }\end{array}$ & Good & - & & N/A & $\begin{array}{l}0.9 \mathrm{~km} \text { made up } \\
\text { of } 4 \text { lanes; } \\
1.1 \mathrm{~km} 2 \text { lanes }\end{array}$ \\
\hline $\begin{array}{l}\text { Igbona- } \\
\text { Okeonitea }\end{array}$ & 2 & 2 & $\begin{array}{l}\text { Well tarred with } \\
\text { bitumen. }\end{array}$ & $\begin{array}{l}\text { Fairly okay } \\
\text { with weeds } \\
\text { in some } \\
\text { part }\end{array}$ & - & & N/A & Smooth surface \\
\hline Total & 49 & & & & 1,456 & 3.9 & & \\
\hline
\end{tabular}




\section{Summary of findings}

The study revealed the existing means of movement within the city which includes; bicycle, trekking, motorcycle, tricycle, taxi, private car and mini-bus (Korope). However the study shows that majority $(31.7 \%)$ of the respondents use motorcycles popularly called "Okada" as their means of transport in the study area. This is closely followed by those who have private car $(30.8 \%)$ and next to it is the use of "Korope" $(24.9 \%)$, the least patronized means of transport is tricycle $(0.5 \%)$ in the study area as it is just recently being introduced as a transport means in the city.

The study revealed a significant relationship between the socio-economic characteristics of people and their mobility pattern. It shows that $54 \%$ of the mobility patterns were accounted for by their socio- economic characteristics. It was observed that education amongst socio-economic characteristics exerted more weight on people's travel pattern, while marital status is the least exerted factor on travel pattern. The study also shows that works/schools are the most trips generated activities area in the city.

The study surveyed 49 kilometers of roads, of which $65.3 \%$ of the roads surveyed made up of two lanes of single carriage way. Most of the roads are characterized with a lot of potholes. The study showed that for an average of $1 \mathrm{~km}$ there are about 30 potholes of various sizes and average depths of $3.9 \mathrm{~cm}$. The field observation revealed that most of the roads in the study area do not have good drainage system which has resulted in storm water that eroded the road ways. The study further revealed that most of the roads have no roads signs to alert the motorists of the road conditions and there is conspicuous absence of street light in the city.

\section{Conclusion}

The result of the findings shows that there is significant relationship between socioeconomic characteristics of the respondents and travel pattern. The study confirms that motorcycle is the most patronized means of transportation because it is fast and easy to come by within the city. The study revealed that most of the roads in the study area are in a state of disrepair without road furniture.

\section{Recommendations}

This study therefore attempts at providing recommendation which could help solve some of the associated problems that has resulted from the urbanization in relation to transportation system.

It is hereby recommended that Government should introduce the use of coaster buses for public transport at affordable charges to discourage present use of motorcycles and private cars in the study area.

Government at all level should increase the efficiency of existing transport operations through improved planning and management of all modes of transport. 
Furthermore, State and Local Governments must offer support service infrastructure in our urban centers to enhance effective and efficient intra-urban mobility pattern, such as bus stations and terminals.

Government is hereby encouraged to invest more on road construction and maintenance. Private investors must also be encouraged to participate in road construction and management through road concession and pricing. Conclusively, it was noted that in the process of various interaction taking place in the city's space, some problems emanated which makes the service rendered by the cities inadequate and unreliable. This required solutions, and in the attempt to provide such solutions a systematic approach is suggested, hence encouraging comprehensive and multi-lateral planning approach to solving cities transportation problems.

\section{References}

[1] Okoko, E (2006): Quantitative techniques in urban analysis, Ibadan, Krafts book limited.

[2] Basorun, J. O and Rotowa, O. O (2012): Regional Assessment of Public Transport Operations in Nigerian Cities: The Case of Lagos Island. International Journal of Developing Societies Vol. 1, No. 2, 2012, 82-87

[3] Abdulkareem Y. A (2002): The Roles and Impacts of Transportation in Nigerian Society http://www.unilorin.edu.ng/publicatios/abdulkareemya

[4] Mabogunje, Akin l. (1968): Urbanization in Nigeria; London: University of London Press Ltd.

[5] Adeniji, K. (1983): Nigeria Municipal Bus Operations Google books Accessed on August 2014

[6] Aderamo, A. J. (2010): "Transport in Nigeria: The Case of Kwara State". African Economic and Business Review Vol. 8 No. 1, Spring 2010. The African Education and Business Research Institute, Inc.

[7] Aderamo, A. J. (2012):Urban transportation problems and challenges in Nigeria: A planner's view. www.primejournals.org/pre

[8] Kombs (1988): Consultancy Report: Traffic Management Schemes in Metropolitan Lagos. Submitted to the Federal Urban Mass Transit Programme (FUMTP).

[9] Wikipedia (2012): Osogbo. www.wikipedia.com

[10] AdedotunS.B, and Adedotun D.O, (2014): 'Road Concession and Pricing: Panacea for Urban Road Sustainable Development in Osun State, Nigeria'. International Journal of Comparative Studies in International Relations and Development Vol 3 No. 1, July 2014 